\title{
HUBUNGAN ANTARA KERACUNAN PESTISIDA DENGAN KEJADIAN ANEMIA PADA PETANI KENTANG DI GABUNGAN KELOMPOK TANI AL-FARRUQ DESA PATAK BANTENG KECAMATAN KEJAJAR KABUPATEN WONOSOBO TAHUN 2016
}

\author{
Rihardini Okvitasari $^{1)}$, Choiroel Anwar ${ }^{2)}$, Suparmin ${ }^{3)}$ \\ Jurusan Kesehatan Lingkungan, Politeknik Kesehatan Kemenkes Semarang, \\ Jl.Raya Baturaden KM 12 Purwokerto, Indonesia
}

\begin{abstract}
Abstrak
Penggunaan pestisida yang tidak terkendali akan berakibat pada kesehatan petani dan lingkungan. Pemeriksaan kadar enzim kholinesterase darah pada petani Wonosobo tahun 2012 menunjukkan bahwa 89,8\% petani menderita keracunan pestisida. Penelitian ini bertujuan untuk mengetahui hubungan antara status gizi, jumlah merk pestisida, dosis, lama kontak, frekuensi penyemprotan, masa kerja, dan penggunaan APD dengan kejadian keracunan pestisida dan mengetahui hubungan antara keracunan pestisida dengan kejadian anemia pada petani kentang. Metode penelitian observasional dengan design crossectional. Jumlah sampel 29 petani kentang. Pengumpulan data dengan pengukuran, pemeriksaan laboratorium, observasi, wawancara, dan pengisian kuesioener. Analisis bivariat menggunakan regresi logistik metode enter dan multivariat menggunakan regresi logitsik metode backward-LR. Hasil uji statistik menunjukkan ada hubungan antara jumlah merk pestisida $(p=0,001)$, penggunaan APD $(p=0,049)$ dan tidak ada hubungan antara status gizi $(p=0,571)$, lama kontak $(p=0,166)$, frekuensi penyemprotan $(p=0,476)$, masa kerja $(p=0,571)$ dengan kejadian keracunan pestisida dan tidak ada hubungan antara keracunan pestisida dengan kejadian anemia. Disimpulkan bahwa petani yang mengalami keracunan 18 orang $(62,1 \%)$ dan tidak ada yang menderita anemia. Disarankan perlu adanya pemeriksaan kadar enzim kholinseterase secara periodik, penyuluhan penggunaan pestisida yang aman, petani menggunakan APD yang lengkap saat bekerja dengan pestisida dan peniliti selanjutnya sebaiknya tidak memeriksa anemia pada petani di dataran tinggi.
\end{abstract}

Kata kunci : Pestisida, Organofosfat, Karbamat, Kholinesterase, Hemoglobin

\begin{abstract}
The use of pesticide which is uncontrollable will give bad impacts to farmers' health and environment. Cholinesterase level examination to farmers' blood in Wonosobo 2012 shows that 889,8\% farmers suffer from pesticide poisonous. This research aims to find out the correlation between nutrient status, the amount of pesticide brands, dosage, contact duration, spray frequency, work time, and APD usage with pesticide poisonous case and find out the correlation of pesticide poisonous with anemia case towards potato farmers. The method used in this research is observational research with cross sectional design. The amount of sample is 29 potato farmers. Data collection used by measurement, laboratory examination, observation, interview, and questionnaire. Bivariate analysis used logistic regression with enter method and multivariate used logistic regression with backward-LR method. The result of statistic test shows that there was a meaningful correlation between the amount of pesticide brands $(p=0,011)$, APD usage $(p=0,049)$ there was no correlation between nutrient status $(p=0,571)$, duration contact $(p=0,166)$, spray frequency $(p=0,476)$, work time $(p=0,571)$ with pesticide poisonous case, and there was no correlation between pesticide poisonous case and anemia case. The conclusion of this research is farmers who suffer from pesticide poisonous are 18 people $(62,1 \%)$ and no one suffers anemia. The researcher suggest to do cholinesterase examination is needed periodically by health official, give counseling about the use safe pesticide by farmer counselor, farmers have to use complete APD when they are working with pesticide, and further research should not check the incidence of anemia in the highland farmers.
\end{abstract}

Keyword : Pesticide, Organophosphate, Karbamat, Cholinesterase, Hemoglobin

1)Rihardini Okvitasari (rihardiniokvitasari@gmail.com)

2) Choiroel Anwar (irul1960@ yahoo.co.id)

${ }^{3)}$ Suparmin (pakparmin@yahoo.com) 


\section{Pendahuluan}

Upaya perlindungan kesehatan masyarakat dalam Peraturan Pemerintah No 66 tahun 2014 tentang Kesehatan Lingkungan Pasal 39 dilakukan untuk mewujudkan lingkungan sehat yang bebas dari unsur yang menimbulkan gangguan kesehatan. Pasal 39 Ayat 2 huruf e menjelaskan unsur yang menimbulkan gangguan kesehatan adalah pestisida.

Penelitian yang dilakukan oleh Prihadi pada tahun 2007 menunjukkan bahwa sebesar $76,47 \%$ petani di Desa Sumberejo Kecamatan Ngablak Kabupaten Magelang mengalami keracunan akibat pestisida dan 60,29\% menderita anemia. Tahun 2012 di Kabupaten Wonosobo telah dilaksanakan pemeriksaan aktivitas enzim kholinesterase pada petani yang menunjukkan hasil 89,8\% mengalami keracunan (LabKesDa Kabupaten Wonosobo, 2012).

Gapoktan Al-Farruq merupakan gabungan kelompok tani kentang yang berada di Desa Patak Banteng Kecamatan Kejajar Kabupaten Wonosobo. Hasil survey pendahuluan pada 19 petani diketahui 14 petani menggunakan pestisida golongan organofosfat dan 9 petani

menggunakan pestisida golongan karbamat. Petani tersebut berpotensi mengalami keracunan karena dalam bekerja tidak menggunakan APD yang lengkap, mencampur berbagai merk pestisida dan menggunakan dosis tidak sesuai anjuran saat penyemprotan. Lama penyemprotan dalam sehari 3-5 jam dengan frekuensi penyemprotan 5 hari sekali saat musim kemarau dan 2 hari sekali saat musim hujan dan sebagian besar masa kerja petani 23 tahun. Belum pernah dilakukan pemeriksaan kadar

enzim kholinesterase dan kadar hemoglobin pada petani di Gapoktan AlFarruq.

Tujuan penelitian adalah mengetahui hubungan antara status gizi, jumlah merk pestisida, dosis, lama kontak, frekuensi penyemprotan, masa kerja, dan penggunaan APD dengan kejadian keracunan pestisida dan mengetahui hubungan antara keracunan pestisida dengan kejadian anemia.

\section{Metode}

Variabel bebas pada penelitian ini adalah keracunan pestisida dan variabel terikatnya kejadian anemia. Terdapat variabel pendahulu yang merupakan variabel yang mempengaruhi variabel bebas yaitu status gizi, jumlah merk pestisida, dosis, lama kontak, frekuensi penyemprotan, masa kerja dan penggunaan APD. Jenis penelitian ini adalah observasional dengan design crossectional. Populasi dalam penelitian ini seluruh petani kentang di Gapoktan Alfarruq dengan jumlah sampel 29 petani berdasarkan kriteria inklusi dan eksklusi. Kriteria inklusi pada penelitian ini adalah petani yang terakhir menggunakan pestisida 2 minggu sebelum hari pelaksanaan penelitian sedangkan kriteria eksklusi yaitu menolak untuk diikutsertakan dalam penelitian. Pengumpulan data dengan pengukuran, pemeriksaan laboratorium, observasi, wawancara, dan pengisian kuesioener. Analisis univariat menggunakan distribusi frekuensi, bivariat menggunakan regresi logistik metode enter dan multivariat menggunakan regresi logistik metode backward-LR.

\section{Hasil dan Pembahasan}

Gambaran Karakteristik Responden

Tabel1DistribusiKarakteristik

Responden

\begin{tabular}{llrr}
\hline Variabel & Deskripsi & Frekuensi & \multicolumn{1}{c}{$\%$} \\
\hline Jenis Kelamin & Laki-laki & 27 & 93,1 \\
& Perempuan & 2 & 6,9 \\
Umur & $\geq 55$ tahun & 3 & 10,3 \\
& $18-54$ & 26 & 89,7 \\
& tahun & & \\
Tingkat & SD & 16 & 53,3 \\
Pendidikan & SMP & 9 & 30 \\
& SMA & 2 & 6,7 \\
& PT & 2 & 6,7 \\
Luas Lahan & $>0,7 \mathrm{Ha}$ & 8 & 26,7 \\
& $\leq 0,7 \mathrm{Ha}$ & 21 & 70 \\
Waktu & 08.00 & 29 & 100 \\
Penyemprotan & $11.00 \mathrm{WIB}$ & & \\
Waktu terakhir & $<2 \mathrm{minggu}$ & 29 & 100 \\
kontak & & & \\
\hline
\end{tabular}

\section{Jenis Kelamin}

Kadar enzim kholinesterase jenis kelamin laki-laki lebih rendah dibandingkan jenis kelamin perempuan karena pada perempuan lebih banyak

mengandung enzim kholinesterase. Berdasarkan hal tersebut, 27 responden memiliki resiko lebih besar mengalami keracunan pestisida.

\section{Umur}

WHO menyatakan kategori umur produktif berada pada rentang 18-54 tahun.

Hasil penelitian Achmadi (1985) menyatakan bahwa ada hubungan antara kadar kholinesterase dengan umur untuk jenis kelamin dimana yang berumur tua kadar kholinesterase cenderung turun (Achmadi, 2012). Berdasarkan hal tersebut 
3 responden dengan kategori umur $>55$ tahun memiliki resiko lebih besar mengalami keracunan pestisida.

\section{Tingkat Pendidikan}

Pendidikan formal yang diperoleh seseorang akan memberikan tambah pengetahuan bagi individu tersebut, dengan tingkat pendidikan yang lebih tinggi diharapkan pengetahuan tentang pestisida dan bahayanya juga lebih baik (Achmadi, 2005). Saat ini pendidikan yang diwajibkan adalah 9 tahun atau terakhir SMP. Berdasarkan hal tersebut 24 responden memiliki resiko lebih besar mengalami keracunan pestisida karena rendahnya tingkat pendidikan petani pada penelitian ini dapat berpengaruh terhadap tingkat pengetahuan mengenai penanganan dan penggunaan pestisida.

\section{Luas Lahan}

Semakin luas lahan maka semakin sering melakukan penyemprotan dan semakin banyak jumlah pestisida yang digunakan. Penelitian yang dilakukan oleh Tampudu, dkk (2010) diketahui jumlah responden yang kadar kholinesterase tidak normal lebih besar pada mereka yang memiliki lahan semprot $<1 \mathrm{Ha}$ daripada jumlah responden yang memilliki lahan semprot >1 Ha. Hasil tersebut sesuai dengan penelitian ini, walaupun responden memiliki luas lahan tidak luas namun dalam bekerja tidak menggunakan APD dan menggunakan dosis yang berlebihan sehingga berpotensi mengalami keracunan pestisida.

\section{Waktu Penyemprotan}

Seluruh responden melakukan penyemprotan pada pukul 08.00-11.00 WIB karena pada lokasi penelitian saat mulai pukul 12.00 WIB cenderung hujan. Waktu penyemprotan berkaitan dengan suhu lingkungan yang dapat menyebabkan keluarnya keringat lebih banyak terutama pada siang hari sehingga lebih mudah terjadinya keracunan terutama penyerapan melalui kulit.

Waktu terakhir kontak dengan pestisida

Waktu terakhir kontak dengan pestisida seluruh responden yaitu <2 minggu dengan rata-rata 2 hari. Penelitian yang dilakukan Suryamah (2006) menemukan nilai $\mathrm{p}<0,05$ dengan odd ratio 5,8 kali untuk mengalami

keracunan dibandingkan dengan petani yang melakukan kontak $>2$ minggu.

\section{Analisis Univariat \\ Kejadian Anemia}

Tabel 2 menunjukkan tidak ada yang menderita anemia karena hasil penelitian ini bias oleh kejadian polisitemia yang cenderung dialami oleh penduduk di daerah dataran tinggi. Jenis polisitemia sekunder yang umum (polisitemia fisiologis) terjadi pada penduduk yang hidup pada ketinggian $420 \mathrm{~m}-510 \mathrm{~m}$. Lokasi penelitian ini berada pada ketinggian 2500 mdpl sehingga dapat menyebabkan jumlah oksigen dalam udara rendah, maka jumlah oksigen yang diangkut ke jaringan kurang, dan produksi sel darah merah meningkat (Hall, 2006).

Tabel 2 Analisis Univariat

\begin{tabular}{llrr}
\hline Variabel & Deskripsi & Frekuensi & \multicolumn{2}{c}{$\%$} \\
\hline Kejadian & Anemia & 0 & 0 \\
Anemia & Normal & 29 & 100 \\
\hline Kejadian & Keracunan & 18 & 62,1 \\
Keracunan & Normal & 11 & 37,9 \\
\hline Status Gizi & Buruk & 4 & 13,8 \\
& Baik & 25 & 86,2 \\
\hline Jumlah & $>3$ merk & 17 & 58,8 \\
Merk & $\leq 3$ merk & 12 & 41,4 \\
\hline Dosis & Tidak sesuai & 29 & 100 \\
& anjuran & & \\
& Sesuai & 0 & 0 \\
& anjuran & & \\
\hline Lama & $>5$ jam & 7 & 24,1 \\
Kontak & $<5$ jam & 22 & 75,9 \\
\hline Frekuensi & $>2 \quad$ kali & 16 & 55,2 \\
Penyem- & seminggu & & \\
protan & $<2 \quad$ kali & 13 & 44,8 \\
& seminggu & & \\
\hline Masa Kerja & $>5$ tahun & 25 & 86,2 \\
& $<5$ tahun & 4 & 13,8 \\
\hline Penggu- & $<5$ jenis & 22 & 75,9 \\
naan APD & $>5$ jenis & 7 & 24,1 \\
\hline & & &
\end{tabular}

\section{Keracunan Pestisida}

Hasil penelitian diketahui golongan pestisida yang paling banyak digunakan adalah ditiokarbamat yaitu 25 responden, organofosfat 20 responden, dan karbamat 14 responden. Kejadian keracunan diakibatkan oleh penggunaan pestisida, Salah satu pestisida yang terkenal menghambat enzim kholinesterase adalah pestisida golongan organofosfat dan karbamat. Tanda dan gejala keracunan pestisida karbamat sama dengan organofosfat namun gejala itu tidak tahan lama dan cepat kembali normal. Pada umumnya pestisida kelompok ini dapat bertahan dalam tubuh antara 1-24 jam sehingga cepat diekskresikan (Raini, 2007).

\section{Status Gizi}

Status gizi pada penelitian diukur berdasarkan indeks masa tubuh. Status gizi dikategorikan baik jika IMT antara 18,5-25 dan buruk jika IMT <18,5 atau >25. Orang yang memiliki tingkat gizi baik cenderung 
memiliki kadar rata-rata kholinesterase lebih besar (Achmadi, 1992). Jika dilihat dari status gizi, maka seluruh responden memiliki kadar kholinesterase yang baik karena tidak ada yang memiliki status gizi rendah (semua IMT>18,5)

\section{Jumlah Merk Pestisida}

Dalam sekali penyemprotan, petani sering mencampur 2-5 merk pestisida. Pada saat penyemprotan penggunaan pestisida >3 jenis dapat mengakibatkan keracunan pada petani (Djojosumarto, 2000). Berdasarkan hal tersebut 17 responden memiliki resiko lebih besar mengalami keracunan pestisida.

\section{Dosis}

Seluruh responden menggunakan dosis tidak sesuai anjuran karena seluruh responden mencampur pestisida dalam setiap penyemprotan, tidak ada yang menimbang pestisida namun mengukur menggunakan sendok sehingga membuat responden lupa jumlah takaran dan sering mereka menambah jumlah takaran berdasarkan kebutuhan. Dosis yang tidak sesuai mempunyai resiko 4 kali untuk

terjadinya keracunan dibandingkan penggunaan dosis yang sesuai aturan (Wudianto, 2007).

\section{Lama Kontak}

Lama kontak dalam penelitian ini merupakan banyaknya waktu kerja responden dalam sehari dimulai dari mencampur, menyemprot, dan mencuci

peralatan. Permenaker No.Per03/Men/1996 pasal 2 ayat 21 menyebutkan bahwa untuk menjaga efek yang tidak diinginkan, maka dianjurkan tenaga kerja yang mengelola pestisida tidak boleh mengalami pemaparan $>5$ jam sehari dan 30 jam dalam seminggu. Berdasarkan hal tersebut 7 responden memiliki resiko lebih besar mengalami keracunan pestisida.

\section{Frekuensi Penyemprotan}

Semakin sering seseorang melakukan penyemprotan, maka semakin tinggi pula resiko keracunannya. (Sasmito, 2006). Waktu yang dianjurkan untuk melakukan kontak dengan pestisida maksimal 2 kali dalam seminggu (Jeyaratnam dan David, 2010). Berdasarkan hal tersebut 16 responden memiliki resiko lebih besar mengalami keracunan pestisida.

\section{Masa Kerja}

Masa kerja merupakan lama waktu sejak responden aktif bekerja dengan pestisida hingga saat penelitian dilakukan. Toksisitas kronis, biasanya terjadi pada masa kerja >5 tahun (Runia, 2008). Berdasarkan hal tersebut 25 responden memiliki resiko lebih besar mengalami keracunan pestisida.

\section{Penggunaan APD}

Pestisida pada umumnya adalah racun bersifat kontak, oleh sebab itu pengunaan APD pada petani waktu menyemprot sangat penting untuk menghindari kontak langsung dengan pestisida (Djojosumarto, 2008). Hasil observasi diketahui, jenis APD yang digunakan mulai dari mencampur, menyemprot, dan mencuci peralatan yaitu sama karena responden

menggunakan APD dari rumah. Berdasarkan hal tersebut 22 responden memiliki resiko lebih besar mengalami keracunan pestisida.

\section{Analisis Bivariat \\ Hubungan antara status gizi dengan kejadian keracunan pestisida}

Tabel 3 menunjukkan tidak ada hubungan antara status gizi dengan

kejadian keracunan pestisida ( $p$ value $=0,571)$. Hasil penelitian ini sejalan dengan penelitian yang dilakukan oleh Prijanto tahun 2009 yang menunjukkan bahwa tidak ada hubungan antara status gizi dengan keracunan pestisida pada istri petani holtikulturan di Desa Sumberejo Kecamatan Ngablak Kabupaten Magelang.

Hasil penelitian berbeda dengan teori yang menyatakan kondisi gizi yang buruk menyebabkan protein yang ada dalam

tubuh sangat terbatas sehingga mengganggu pembentukan enzim kholineseterase (Achmadi, 1992). Hal tersebut dipengaruhi oleh jumlah merk

pestisida dan penggunaan APD. Responden yang memiliki status gizi baik namun menggunakan alat pelindung diri tidak lengkap saat bekerja dengan pestisida, jumlahnya lebih besar dari responden yang menggunakan alat pelindung diri lengkap saat bekerja dengan pestisida dan terdapat 14 responden dengan gizi yang baik namun dalam sekali penyemprotan menggunakan >3 merk pestisida.

Pestisida masuk kedalam tubuh melalui pernafasan, mulut, dan kulit. Akibat pemakaian APD yang tidak lengkap ditambah pemakaian pestisida yang

bermacam-macam maka akan memudahkan tubuh mengalami keracunan pestisida. Responden sebaiknya berhatihati dalam menggunakan pestisida salah satunya dengan mencampur pestisida sesuai anjuran label dan menggunakan APD yang lengkap saat kontak dengan pestisida 
Tabel 3 Analisis Bivariat

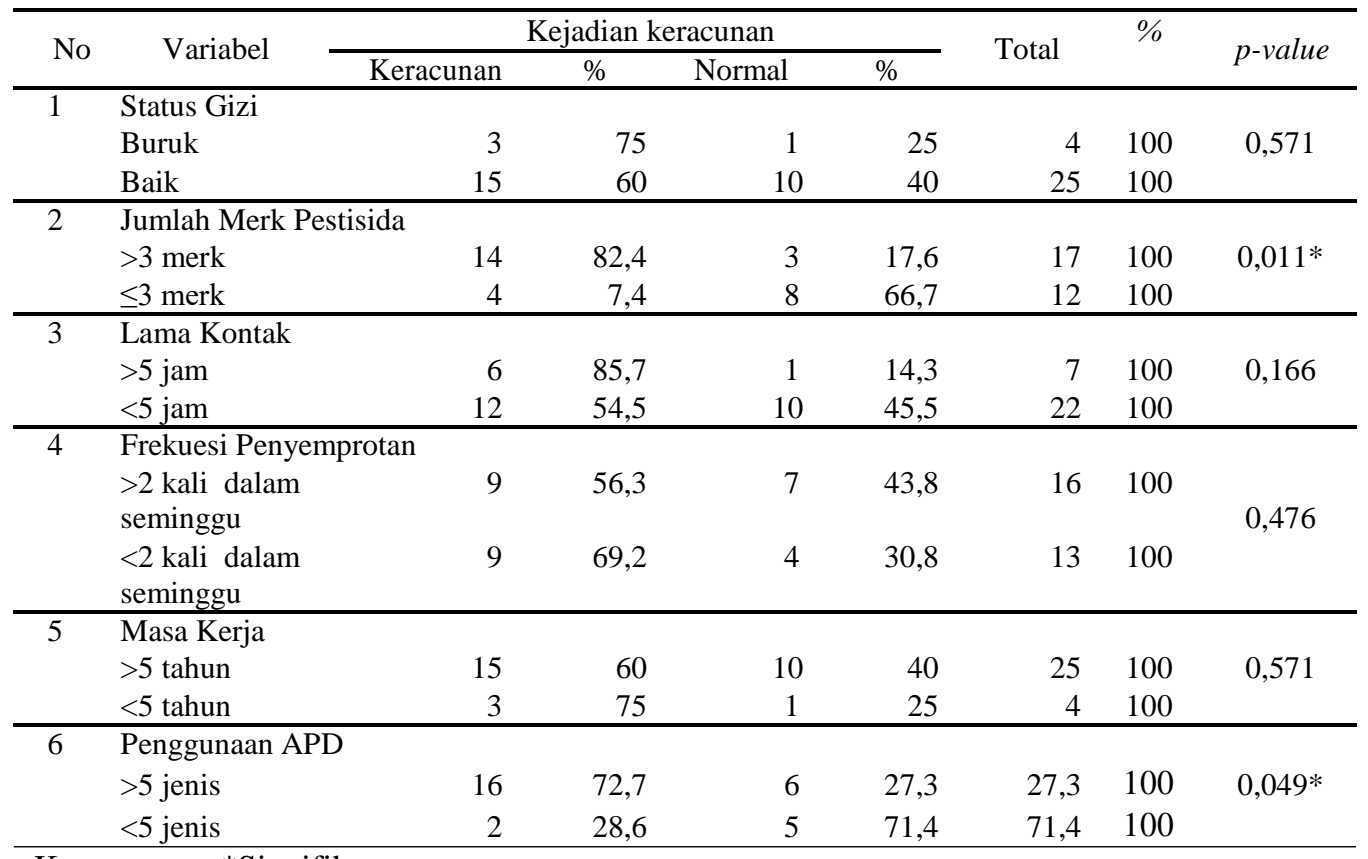

Keterangan : *Signifikan

\section{Hubungan antara jumlah merk dengan kejadian keracunan pestisida}

Ada hubungan antara jumlah merk pestisida dengan kejadian keracunan pestisida $(p$-value $=0,011)$. Hasil penelitian ini sesuai dengan penelitian yang dilakukan oleh Isnawan tahun 2013 yang menyatakan ada hubungan antara jumlah pestisida yang digunakan petani dengan kejadian keracunan pestisida pada petani bawang merah di Desa Kedunguter Kecamatan Brebes Kabupaten Brebes dengan nilai $\mathrm{p} 0,043$.

Dalam sekali penyemprotan, responden mencampur 2-5 merk pestisida. Golongan pestisida yang banyak digunakan yaitu ditiokarbamat, organofosfat, urea dan karbamat. Responden sering mencampur pestisida golongan organofosfat dengan karabamat atau ditiokarbamat bahkan pestisida yang satu golongan namun berbeda bahan aktif. Secara toksikologi, bila dua insektisida organofosfat diberikan secara bersamaan maka akan menimbulkan efek yang aditif, artinya suatu situasi dimana efek gabungan dari dua pestisida yang sama dengan jumlah dari efek masing-masing pestisida bila diberikan sendiri, sehingga daya racun semakin kuat (Priyanto, 2007).

Masing-masing pestisida mempunyai efek fisiologis yang berbeda-beda tergantung dari kandungan zat aktif dan sifat fisik dari pestisida tersebut. Pada saat penyemprotan penggunaan pestisida $\geq 3$ jenis dapat mengakibatkan keracunan pada petani. Banyaknya pestisida yang digunakan menyebabkan beragamnya paparan pada tubuh petani yang mengakibatkan reaksi sinergik dalam tubuh (Djojosumarto, 2000 hal 23).

Responden sebaiknya dalam mencampur pestisida memperhatikan anjuran pada label kemasan perlunya penyuluhan dari pemerintah mengenai efek masing-masing bahan aktif terhadap kesehatan.

\section{Hubungan antara dosis dengan} kejadian keracunan pestisida

Tidak ada hubungan antara dosis dengan kejadian keracunan karena seluruh responden tidak ada yang menggunakan dosis sesuai anjuran. Hasil penelitian ini sejalan dengan penelitian yang dilakukan oleh Mulyani tahun 2011 pada petani bawang merah di Desa Tegalgandu Kecamatan Wanasari Kabupaten Brebes bahwa dari 45 responden, seluruh responden tidak ada yang menggunakan dosis pestisida sesuai anjuran sehingga diketahui tidak ada hubungan antara dosis pestisida dengan aktivitas enzim kholinesterase darah.

Penelitian ini tidak sesuai dengan teori yang menyatakan bahwa dosis yang semakin besar maka akan semakin besar terjadinya keracunan pestisida. Karena bila dosis penggunaan pestisida bertambah, maka efek dari pestisida juga akan bertambah. Hal tersebut karena di pengaruhi oleh waktu kontak responden dengan pestisida. Dosis dapat dinyatakan 
sebagai hasil kali kadar $(C)$ dan waktu $(t)$. Diketahui bahwa bila hasil kali $C$ x $t$ tetap, responnya akan sama. Namun, aturan ini tidak berlaku bila $C$ atau $t$ merupakan suatu nilai ekstrem. Contohnya kalau $C$ terlalu kecil, tidak ada respons yang akan diperoleh berapapun lamanya hewan terpajan padanya (Lu, 1995).

Hasil penelitian diketahui 75,9\% responden memiliki lama kontak dengan pestisida $<5$ jam sehari dan 93,1\% responden memiliki lama kontak dalam seminggu <30 jam. Dipengaruhi juga oleh bahan aktif pestisida yang digunakan, diketahui 25 responden menggunakan fungisida dengan bahan aktif mankozeb yang merupakan pestisida dari golongan ditiokarbamat. Efek farmakologis pestisida golongan ditiokarbamat dapat menghambat enzim kholinesterase. Gejala keracunan pestisida ditiokarbamat bersifat reversible, sehingga penderita akan cepat sembuh kembali (Tomlin dan Wayland dalam Mutiatikum dkk, 2003).

Responden sebaiknya mempertahankan waktu kontak di bawah standar dan pemerintah sebaiknya memberikan pengertian dan pemahaman mengenai efek dari pemakaian dosis yang berlebihan kepada petani.

\section{Hubungan antara Lama Kontak dengan kejadian keracunan pestisida}

Tidak ada hubungan antara lama kontak dengan kejadian keracunan pestisida ( $p$-value=0,166). Hal tersebut karena $75,9 \%$ responden memiliki lama kontak dengan pestisida dibawah batas maksimal (<5 jam sehari). Hasil penelitian ini sejalan dengan penelitian yang dilakukan oleh Zuraida tahun 2011 yang menyatakan tidak ada hubungan yang signifikan antara lama kontak dengan tingkat keracunan pestisida pada petani di Desa Srimahi Tambun Utara Bekasi dengan $p$-value $=0,219$.

Praktik pencampuran yang dilakukan petani tergolong baik karena seluruh responden melakukan pencampuran dilahan, menggunakan pengaduk khusus, serta menggunakan ember khusus. Hal ini sesuai dengan teori yang menyatakan bahwa pencampuran pestisida sebaiknya dilakukan di tempat yang memiliki sirkulasi udara yang baik karena ditempat tertutup pestisida memiliki daya racun yang tinggi sehingga dapat mengakibatkan keracunan melalui pernafasan (Soemirat, 2003).

Hasil wawancara pada 29 responden diketahui 18 orang melakukan pencucian alat setelah penyemprotan. Berdasarkan pengamatan dilapangan, responden mencuci peralatan di lahan menggunakan air dari lahan yang biasa petani sebut dengan "kalenan". Hal ini dapat mengurangi resiko kontak petani dengan pestisida selama perjalanan dari lahan menuju rumah.

Penyimpanan pestisida yang dilakukan oleh responden tergolong baik karena dari 29 responden yang melakukan penyimpanan seluruh responden menyimpan pestisida dalam kemasan asli, 25 orang menyimpan pestisida dalam

ruangan yang jauh dari dapur/penyimpanan makanan, 28 orang menyimpan pestisida dalam ruangan yang ada ventilasinya, dan seluruh responden menyimpan pestisida pada tempat yang tidak langsung terkena sinar matahari. Hal ini sesuai dengan pernyataan Sudarmo (1992) bahwa pestisida harus disimpan di tempat yang khusus dan dikunci agar jauh dari jangkauan anak-anak dan tidak terkena sinar matahari langsung untuk mengurangi faktor terjadinya penguapan akibat reaksi kimia dan fisika bahan kimia pestisida dengan udara.

Responden sebaiknya mempertahankan waktu kontak dibawah standar dan sikap yang baik saat bekerja dengan pestisida.

\section{Hubungan antara Frekuensi \\ Penyemprotan dengan kejadian keracunan pestisida}

Tidak ada hubungan antara frekuensi penyemprotan dengan kejadian keracunan pestisida ( $p$-value $=0,476)$. Hasil penelitian ini sejalan dengan penelitian yang dilakukan oleh Yuantari tahun 2009 pada petani holtikultura di Desa Sumberejo Kecamatan Ngablak Kabupaten Magelang yang menyatakan tidak ada hubungan antara frekuensi penyemprotan dengan

keracunan pestisida dengan $p$-value $=$ 0,478 .

Tidak ada hubungan pada penelitian ini karena dipengaruhi oleh waktu kontak responden dengan pestisida. Berdasarkan hasil penelitian diketahui 93,1\% responden memiliki lama kontak dengan pestisida dalam seminggu $<30$ jam. Menurut Permenaker No.Per-03/Men/1986 pasal 2 ayat 21 menyebutkan bahwa untuk menjaga efek yang tidak diinginkan, maka dianjurkan tenaga kerja yang mengelola pestisida tidak boleh mengalami pemaparan $>30$ jam dalam seminggu. Sehingga walaupun responden memiliki frekuensi $>2$ kali dalam seminggu namun jika lama kontak dengan pestisida dibawah 
standar maka resiko terjadinya keracunan dapat diminimalisir.

Hasil penelitian menunjukkan terdapat $72,4 \%$ responden yang dalam praktik penyemprotan mengikuti arah angin, $55,1 \%$ menyemprot tidak sambil merokok, $75,8 \%$ tidak makan dan minum pada saat setelah penyemprotan, dan $27,5 \%$ cuci tangan pakai sabun setelah melakukan penyemprotan. Masih terdapat responden yang memiliki tindakan buruk saat penyemprotan seperti merokok dan makan tanpa cuci tangan pakai sabun sehingga pestisida dapat masuk kedalam tubuh melalui mulut (Oral/Portal entry).

Portal entry ini sering dan mudah terjadi namun bahan asing yang masuk tidak akan mudah mencapai peredaran darah karena beberapa hal penting yang terkait pada fungsi saluran gastrointestinal. Di mulut xenobiotik bercampur dengan ludah yang mengandung enzim, di dalam lambung xenobiotik yang tidak tahan asam akan dihancurkan oleh asam lambung, di usus halus akan bertemu dengan enzim usus halus yang bersifat basa sehingga xenobiotik asam akan ternetralisir, dan seterusnya hingga terbuang melalui usus besar. Proses absorbsi terjadi melalui mukosa usus, yang selanjutnya mengalir mengikuti sistem sirkulasi darah. (Suwindre, 1993 dalam Rustia, 2009)

Sebaiknya responden tidak merokok sambil menyemprot, tidak makan minum sambil menyemprot dan perlunya penyuluhan kepada petani mengenai pentingnya membersihkan anggota tubuh dengan sabun setelah selesai kontak dengan pestisida.

\section{Hubungan antara Masa Kerja dengan kejadian keracunan pestisida}

Tidak ada hubungan antara masa kerja dengan kejadian keracunan pestisida ( $p$ value $=0,571)$. Penelitian ini sejalan dengan penelitian yang dilakukan oleh Isnawan tahun 2013 pada petani bawang merah di Desa Kedunguter Kecamatan Brebes Kabupaten Brebes yang menyatakan bahwa tidak ada hubungan antara masa kerja petani dengan kejadian keracunan pestisida pada petani bawang merah dengan nilai $p$-value 0,324 .

Hasil penelitian berbeda dengan teori yang menyatakan bahwa sebagai petani, semakin lama bekerja menjadi petani akan semakin sering kontak dengan pestisida sehingga risiko keracunan pestisida semakin tinggi. Seseorang yang bekerja di lingkungan yang mengandung pestisida semakin besar kemungkinan untuk terjadinya pajanan oleh pestisida, sehingga semakin besar pula kemungkinan untuk terjadinya keracunan disebabkan karena banyak kontak dan menghirupnya (Sartono, 2002).

Dalam satu tahun responden tidak melakukan kegiatan penyemprotan tanaman kentang secara terus menerus. Dari hasil penelitian diketahui terdapat 19 responden yang dalam satu tahun mereka menaman tanaman seperti cabe, wortel, kubis, dan carica dimana selama masa tanam tidak membutuhkan pestisida. Dalam satu musim, tanaman kentang butuh penyemprotan 15-25 kali yaitu dari umur 2 hari setelah tanam sampai umur 90 hari. 20 hari sebelum panen, penyemprotan dihentikan karena petani beranggapan jika tidak seperti itu maka residu pestisida akan terdeteksi pada saat kentang sudah dipasaran. Sehingga ada waktu bagi petani untuk istirahat menaikkan kembali kadar enzim kholinesterase dalam darah karena waktu untuk istirahat lebih lama dari pada waktu penyemprotan.

Penelitian yang dilakukan oleh Raini tahun 2000 pada 80 petani penyemprot pestisida yang keracunan pestisida dengan kholinesterase $\leq 75 \%$, rata-rata subyek memerlukan waktu pemulihan kembali 1 minggu dan untuk kholinesterase $\leq 62,5 \%$ memerlukan waktu 2 minggu.

Pertahankan pola tanam yang variatif supaya ada waktu istirahat untuk menormalkan kadar enzim kholinesterase dalam darah, ikutilah petunjuk mengenai waktu penggunaan terutama mengenai jangka waktu antara penyemprotan pestisida terakhir dengan waktu panen sehingga tidak ada residu pestisida pada tanaman yang telah dipanen yang dapat membahayakan kesehatan manusia, dan Dinas Kesehatan sebaiknya melakukan pemeriksaan kadar enzim kholinesterase secara periodik.

Hubungan antara Penggunaan APD dengan kejadian keracunan pestisida

Ada hubungan antara penggunaan APD dengan kejadian keracuan pestisida $(p$-value $=0,047)$. Hasil penelitian ini sejalan dengan penelitian yang dilakukan oleh Budiawan tahun 2013 yang menyatakan ada hubungan antara tingkat pemakaian APD dengan kholinesterase petani bawang merah di Desa Ngurensiti Kecamatan Wedarijaksa Kabupaten Pati dengan $p$-value $=0,047$.

Kaca mata merupakan jenis APD yang tidak digunakan oleh seluruh responden 
dengan alasan malu dan terlihat gaya. Kacamata pelindung harus dikenakan saat menangani cairan kimia yang berbahaya dimana mata dapat terkespos pada bahan kimiawi yang berbahaya baik dalam bentuk padat maupun cair. Mata juga merupakan bagian dari jalur masuknya pestisida yang mudah sekali meresapkan pestisida.

APD yang jarang digunakan selain kaca mata yaitu kaos tangan karena hanya $24,1 \%$ responden yang memakainya. Kaos tangan yang dipakai yaitu ada yang berbahan karet namun ada yang berbahan kain. Kaos tangan merupakan APD yang penting terutama saat mencampur pestisida. Diketahui juga jumlah responden yang menggunakan sepatu boots 48,2\%, baju lengan panjang dan celana panjang $75,8 \%$ dan penutup kepala 79,3\%. Alasan responden tidak mau memakai APD yang lengkap karena mengganggu pekerjaan terutama sepatu boots jika digunakan dapat merusak tanaman. Berdasarkan observasi dilapangan, saat tanaman kentang berumur 25-30 hari, tinggi tanaman baru sekitar 30 $\mathrm{cm}$ sehingga arah penyemprotan ke bawah dekat kaki. Namun, dalam penyemprotan petani tidak menggunakan sepatu boots sehingga pestisida banyak yang masuk melalui kulit karena kulit merupakan organ yang penting untuk absorbsi xenobiotika.

Penutup wajah termasuk APD yang jarang digunakan oleh responden. Dari hasil penelitian diketahui $27,5 \%$ responden menggunakan penutup wajah saat bekerja dengan pestisida. Penutup wajah yang digunakanpun belum memenuhi syarat karena saat dilapangan ditemukan penutup wajah yang digunakan merupakan kaos panjang yang diikat untuk menutupi hidung. Pada penelitian ini $100 \%$ aplikasi pestisida dilakukan dengan cara disemprotkan, sehingga memungkinkan butir-butir cairan tersebut melayang, menyimpang dari aplikasi. Jarak yang ditempuh oleh butiran-butiran cairan tergantung pada ukuran butiran. Butiran dengan radius kecil dari satu micron, dapat dianggap sebagai gas yang kecepatan mengendapnya tak terhingga, sedang butiran dengan radius yang lebih besar akan lebih cepat mengendap (Sudarmo, 1991).

Perlunya peningkatan penyuluhan mengenai pentingnya penggunaan APD yang lengkap dan bantuan keringanan harga APD yang terjangkau oleh petani.

\section{Hubungan antara keracunan pestisida dengan kejadian anemia}

Hasil pemeriksaan kadar Hemoglobin (Hb) darah pada 29 responden diketahui tidak ada yang menderita anemia. Kejadian anemia dapat terjadi pada penderita keracunan organofosfat dan karbamat

adalah karena terbentuknya sulfhemoglobin dan methemoglobin di dalam sel darah merah. Sulfhemoglobin terjadi karena kandungan sulfur yang tinggi pada pestisida sehingga menimbulka ikatan hemoglobin dengan atom sulfur. Methemoglobin terbentuk ketika zat besi di dalam $\mathrm{Hb}$ teroksidasi dari ferro menjadi ferri dan dapat disebabkan karena terjadi ikatan nitrit dengan $\mathrm{Hb}$ sehingga $\mathrm{Hb}$ tidak mampu mengikat oksigen dan terjadi anemia hemolitik (Pinkhas et.al dalam Runia, 2008).

Tidak adanya responden yang menderita anemia pada penelitian ini di pengaruhi oleh status gizi. Status gizi pada penelitian ini ditentukan berdasarkan Indeks Masa Tubuh (IMT), dari 29 responden yang diperiksa tidak ada yang memiliki IMT rendah atau semua IMT responden $>18,5$. Hal ini sesuai dengan pendapat Thompson tahun 2007 yang diacu dalam Kurniasih tahun 2013, status gizi mempunyai korelasi positif dengan konsenterasi hemoglobin, artinya semakin buruk status gizi seseorang maka semakin rendah kadar hemoglobinnya.

Hasil penelitian ini sesuai dengan penelitian yang dilakukan oleh Runia (2008) terhadap petani holitikultura di desa Tejosari Kecamatan Ngablak Kabupaten Magelang yaitu dari 75 petani didapatkan 63 petani menderita anemia tetapi tidak didapatkan hubungan antara penggunaan pestisida dengan kejadian anemia karena anemia yang diderita petani merupakan akibat dari status gizi yang dimiliki petani yang juga diukur berdasarkan IMT.

Penelitian yang dilakukan oleh Kurniasih, dkk pada tahun 2013 menunjukkan ada hubungan antara paparan pestisida dengan kejadian anemia pada petani Holtikultura di Desa Gombong kecamatan Belik Kabupaten Pemalang. Sedangkan Desa Gombong merupakan wilayah pegunungan dengan ketinggian 1.050 mdpl. Hasil uji multivariat menunjukkan bahwa paparan pestisida berpengaruh terhadap kejadian anemia dengan $p$-value 0,043 dan paparan pestisida memiliki kecenderungan 5,333 kali lebih besar berpengaruh mengalami kejadian anemia dibandingkan dengan 
responden yang tidak terpapar pestisida dalam tubuh.

Hal yang membedakan penelitian ini dengan penelitian Kurniasih, dkk yaitu dari ketinggian tempat yang berpengaruh terhadap kejadian anemia. Lokasi penelitian ini yaitu Desa Patak Banteng yang berada pada ketinggian $2500 \mathrm{mdpl}$. Semakin tinggi suatu daerah maka tekanan udara akan semakin rendah. Dengan keadaan yang demikian maka tubuh yang kekurangan oksigen akan memproduksi sel darah merah lebih banyak untuk meningkatkan kadar oksigen dalam tubuh sehingga darahpun menjadi kental.

Dataran tinggi memiliki pengaruh terhadap kadar hemoglobin pada suatu individu. Berada di Ketinggian akan menyebabkan hipoksia oleh karena tekanan parsial oksigen yang berkurang dan tubuh akan merespon dengan proses aklimatisasi. Dengan adanya proses aklimatisasi maka akan terjadi peningkatan pada kadar hemoglobin untuk beradaptasi dengan keadaan rendah oksigen. (Waani, dkk, 2014). Penelitian yang dilakukan oleh Beall, dkk pada penduduk Tibet dengan ketinggian $4000 \mathrm{~m}$ dan Aymara Bolivia dengan ketinggian $4065 \mathrm{~m}$ diatas permukaan laut, menunjukkan perbedaan hemoglobin penduduk dari kedua daerah tersebut. Penduduk laki-laki dan perempuan di daerah Tibet mempunyai kadar hemoglobin 3,5 - 3,6 gm/dl lebih rendah dari penduduk Aymara di Bolivia.

Responden sebaiknya mempertahankan status gizi yang baik dan menjaga kontak dengan pestisida yang tidak berturut-turut dalam seminggu sehingga ada waktu istirahat untuk menormalkan kadar Enzim kholinesterase dalam darah yang dapat mencegah kejadian anemia pada petani.

\section{Analisis Multivariat}

Tabel 4 Analisis Multivariat

\begin{tabular}{llll}
\hline Variabel & $p$-value & $\operatorname{Exp}(\mathrm{B})$ & CI \\
\hline Jumlah Merk & $0,019^{*}$ & 9,653 & $1,452-$ \\
& & & 64,194 \\
Lama Kontak & 0,432 & 2.584 & $0,209-$ \\
& & & 39,013 \\
Penggunaan & 0,081 & 7,001 & $0,784-$ \\
APD & & & 62,520 \\
\hline
\end{tabular}

*Signifikan

Tabel 4 menunjukkan lama kontak dan penggunaan APD tidak berpengaruh terhadap kejadian keracunan pestisida karena pada analisis multivariat, variabel tersebut bersaing dengan variabel lain. Variabel yang berpengaruh terhadap kejadian keracunan pestisida adalah jumlah merk pestisida dengan $p$-value
0,019 dan $\exp (B)=9,653$. Artinya responden yang menggunakan pestisida $>3$ merk dalam sekali penyemprotan memiliki resiko 9,653 kali lebih besar mengalami keracunan dibanding responden yang menggunakan jumlah pestisida $<3$ merk.

Hasil analisis interaksi antara Jumlah merk pestisida dengan penggunaan APD di ketahui $p$-value $=0,205$ sehingga tidak ada interaksi antara jumlah merk pestisida dengan penggunaan APD. Tidak signifikan penggunaan APD karena di pengaruhi oleh toksisitas pestisida yang digunakan. Hasil penelitian diketahui merk yang paling banyak digunakan adalah Manteb 80 WP dengan bahan aktif mankozeb yang memiliki LD50 5000 mg/kg dan merk Daconil dengan bahan aktif Khlorotalonil yang memiliki LD50 $10.000 \mathrm{mg} / \mathrm{kg}$, dua merk tersebut termasuk dalam kelas sedikit beracun (toksisitas rendah).

Permenkes No.258/Menkes/Per/III/ 1992 tentang persyaratan Pengelolaan Pestisida menyatakan untuk perlengkapan pelindung minimal yang harus digunakan berdasarkan jenis pekerjaan dan klasifikasi pestisida khusus penyemprotan di luar gedung dengan klasifikasi pestisida yang cukup berbahaya yaitu sepatu kanvas, baju terusan lengan panjang dan celana panjang. Berdasarkan hal tersebut petani yang bekerja dengan APD tidak lengkap yaitu masker dan sepatu boots dapat memudahkan pestisida masuk ke dalam

tubuh namun tidak menimbulkan keracunan karena toksisitas pestisida yang rendah.

\section{Simpulan dan Saran Simpulan}

Hasil analisis bivariat diketahui ada hubungan antara jumlah merk pestisida $(\mathrm{p}=0,001)$, penggunaan APD $(\mathrm{p}=0,049)$ dan tidak ada hubungan antara status gizi $(\mathrm{p}=0,571)$, lama kontak $(\mathrm{p}=0,166)$, frekuensi penyemprotan $(\mathrm{p}=0,476)$, masa kerja $\quad(p=0,571)$ dengan kejadian keracunan pestisida. Analisis multivariat diketahui jumlah merk pestisida berpengaruh dengan kejadian keracunan pestisida $(p=0,019)$. Jumlah responden yang menderita keracunan yaitu 18 orang $(62,1 \%)$ dan tidak ada penderita anemia.

\section{Saran}

Perlu adanya pemeriksaan kadar enzim kholinseterase secara periodik oleh petugas kesehatan, penyuluhan penggunaan pestisida yang aman oleh petugas penyuluh pertanian, petani menggunakan APD yang lengkap saat bekerja dengan pestisida dan 
peniliti selanjutnya sebaiknya tidak memeriksa anemia pada petani di dataran tinggi karena masyarakat di dataran tinggi cenderung mengalami polisitemia.

\section{Ucapan Terima Kasih}

Penelitian ini, peneliti mendapatkan bantuan dana dari Dinas Kesehatan Kabupaten Wonosobo dan kerjasama dari Ketua Gapoktan Al-Farruq serta Kepala Desa Patak Banteng Kecamatan Kejajar Kabupaten Wonosobo, untuk itu peneliti mengucapkan terima kasih dan semoga penelitian ini bermanfaat.

\section{Daftar Pustaka}

Achmadi, UF. (1992). Aspek Kesehatan Kerja Sektor Informal . Jakarta : Depkes RI.

. (2005).Manajemen Penyakit Berbasis Wilayah. Jakarta: Kompas .(2012). Manajemen Penyakit Berbasis Wilayah. Edisi Revisi. Jakarta : Rajawali Pers

Budiyawan, (2014). Faktor Resiko yang Berhubungan dengan Cholinesterase pada Petani Bawang Merah di Ngurensiti Pati. from http://journal.unnes.ac.id./sju/index.p hp/ujph diakses pada Kamis, 25 Februari 2016 pukul 17.30 WIB

Budiyono, (2004). Hubungan Pemaparan Pestisida dengan Gangguan Kesehatan Petani Bawang Merah di Kelurahan Panekan Kecamatan Magetan. Media Kesehatan Masyarakat Indonesia, Volume III, nomor 2, Oktober 2004, hlm 43-48. Di akses pada Kamis, 25 Februari 2016 pukul 17.00 WIB

Djau RA, (2009) Faktor Resiko Kejadian Anemia dan Keracunan Petisida pada Pekerja Penyemprot Gulma di Kebun Kelapa Sawit PT. Agro Indomas Kabupaten Seruyan Kalimantan Tengah. Tesis. Semarang: Program Studi Magister Kesehatan Lingkungan Universitas Diponegoro

Djojosumarto P, (2000). Teknik Aplikasi Pestisida Pertanian. Yogyakarta: Kanisius

,(2008). Pestisida dan Aplikasinya. Yogyakarta: Kanisius.

Duriat, A.S., dkk, (2006). Penerapan teknologi PHT pada Tanaman Kentang. Balitsa.
Ekha I, (1998) Dilema Pestisida. Yogyakarta : Kanisius

Guyton and Hall, (2007). Buku Ajar Fisiologi untuk Kedokteran. Jarkarta : EGC

Isnawan RM (2013). Faktor-Faktor yang Berhubungan dengan Kejadian Keracunan Pestisida pada Petani Bawang Merah di Desa Kedunguter Kecamatan Brebes Kabupaten Brebes. from Jurnal Kesehatan Masyarakat volume 2, Nomor 1, Tahun 2013 diakses pada 10 Oktober 2015 pukul 19.00 WIB

Jayaratnam J dan David K, (2010). Buku ajar praktik kedokteran kerja. Jakarta: EGC

Kurniasih, dkk, (2013). Faktor-Faktor yang Terkait Paparan Pestisida dan Hubungannya dengan Kejadian Anemia pada Petani Holtikultura di Desa Gombong Kecamatan Belik Kabupaten Pemalang Jawa Tengah. from Jurnal Kesehatan Lingkungan Indonesia Vol. 12 No.2 / Oktober 2013 diakses pada 1 Maret 2016 pukul 06.00 WIB

Lu FC, (1995). Toksikologi Dasar. Edisi 2. Jakarta : UI Press

Mulyani N, (2011), Studi Faktor-Faktor yang Berhubungan Dengan Aktivitas Enzim Cholinesterase Darah pada Petani Bawang Merah di Desa Tegalgandu Kecamatan Wanasari Kabupaten Brebes Tahun 2011. Purwokerto : Karya Tulis Ilmiah D3 Kesehatan Lingkungan Poltekkes Semarang

Murray RK, dkk, (1999). Biokimia Harper. Edisi 24. Jakarta : EGC

Mutiatikum D, dkk, (2003). Profil Residu Pestisida Ditiokarbamat dalam Tomat dan Selada pada Tingkat Konsumen di DKI Jakarta. Jurnal Media Litbang Kesehatan Voume XII Nomor 4 tahun 2003

Patil JA, Patil AJ, Govindwar SP. 2003, Biochemical Effects of Various Pesticides on Sprayers of Grape gardens. indian journal of clinical biochemistry.

http://www.ncbi.nlm.nih.gov/pmc/arti cles/PMC3453870/pdf/12291_2008_ Article_BF02867362.pdf

Pearce EC, (2009). Fisiologi Kedoketeran. Jakarta : EGC

Persetya, Enggarwati, E, Wibawa, A. (2010). hubungan factor-faktor paparan pestisida terhadap kadar kolinestrase pada petani penyemprot 
Tembakau di Desa Karangjati, Kabupaten Ngawi.

Prabowo K, (2001). Hubungan antara Karakteristik Individu dan Pekerjaan dengan Aktivitas Cholinesterase Darah pada Petani Pengguna Pestisida di Kabupaten Bandung Tahun 2001. Tesis. Depok : Program Studi Magister Fakultas Kesehatan Masyarakat Universitas Indonesia

PriceSA dan Wilson LM, (2006). Patofisiologi Konsep klinis prosesproses penyakit. Jakarta : EGC

Prihadi, (2007). Faktor-Faktor yang Berhubungan dengan Efek Kronis Keracunan Pestisida Organofosfat pada Petani Sayuran di Kecamatan Ngablak Kabupaten Magelang. Tesis. Semarang : Program Studi Magister Kesehatan Lingkungan Universitas Diponegoro

Prijanto TB, (2009). Analisis Faktor Resiko Keracunan Pestisida Organofosfat pada Keluarga Petani Hortikultura di Kecamatan Ngablak Kabupaten Magelang. Tesis. Semarang: Program Studi Magister Kesehatan Lingkungan Universitas Diponegoro

Priyanto, (2007). Toksisitas Obat, Zat Kimia dan Terapi Antidotum. Depok : Leskonfli

Purba, IG, (2009). Analisis Faktor-Faktor yang Berhubungan dengan Kadar Kholinesterase pada Perempuan Usia Subur Di Daerah Pertanian. Tesis. Semarang: Program Studi Magister Kesehatan Lingkungan Universitas Diponegoro

Raini M, (2001). Sikap dan Perilaku Buruh Penyemprot yang Keracunan Pestisida Organofosfat di Kecamatan Pacet Jawa Barat, Media. Penelitian dan Pengembangan. Vol. XI No 2, 21-25.

(2004). Pengaruh Istirahat terhadap Aktivitas Kolinesterase Petani Penyemprot Pestisida Organofosfat di Kecamatan PacetJawa Barat. Bulletin Peneliitian Kesehatan, Jurnal vol. 32 No.3. 105110. diakses tanggal 1 Februari 2016 pukul 06.00 WIB

, (2007). Toksikologi Pestisida dan Penanganan Akibat Keracunan Pestisida. from Jurnal Media Litbang Kesehatan Volume XVII Nomor 3. Diakses pada Jumat, 9 Oktober 2015 pukul 17.00 WIB
Reddy PB dan Kanoija J, (2012). Clinico Pathological Effects of Pesticides Exposure on Farm Workers. DAV International Journal of Science. 2012 (2): 191-121 diakses tanggal 1 Juni 2016 pukul 06.00 WIB

Runia YA, (2008). Faktor-Faktor yang Berhubungan dengan Keracunan Pestisida Organofosfat, Karbamat dan Kejadian Anemia pada Petani Hortikultura di Desa Tejosari Kecamatan Ngablak kabupaten Magelang. Tesis. Semarang: Program Studi Magister Kesehatan Lingkungan Universitas Diponegoro

Rustia N, (2009). Pengaruh Pajanan Pestisida. Jurnal Kesehatan Lingkungan, Depok: Universitas Indonesia

Sartono, (2002). Racun dan Keracunan. Jakarta : Widya Medika

Sasmito, (2006). Kandungan Enzim Kholinesterase dan Icreatendi pada Petani Penebar Pestisida di Kabupaten Brebes. Majalah Farmasi Indonesia 1996, VII(2).

Sherwood L, (2001). Fisiologi Manusia. Edisi 2. Jakarta : EGC

Silvia dan Loraine, (2006). Patofisiologis Konsep Klinis Proses-Proses Penyakit Volume 1. Edisi VI. Jakarta : EGC

Siwiendrayanti A, dkk, (2012). Hubungan Riwayat Pajanan Pestisida dengan Kejadian Gangguan Fungsi Hati (Studi pada Wanita Usia Subur di Kecamatan Kersana Kabupaten Brebes. Jurnal Kesehatan Lingkungan Indonesia Vol 11 No.1 / April 2012 diakses pada 1 Maret 2016 pukul 07.00 WIB

Soemirat J, (2003). Toksikologi Lingkungan, Yogayakarta : Gadjah Mada University Press

Sudarmo S, (1991). Pestisida. Yogyakarta : Kanisius _ (1992). Pestisida untuk tanaman. Yogyakarta : Kanisius

Syaifuddin, (2012). Anatomi Fisiologi. Jakarta: EGC

Untung, K, (2006). Pengantar Pengelolaan Hama Terpadu (Edisi Kedua), Yogyakarta: Gadjah Mada University Press.

Waani, dkk, (2014). Kadar Hemoglobin pada Orang Dewasa yang Tinggal di Dataran Tinggi dengan Ketinggian yang Berbeda. Jurnal e-Biomedik, volume 2, Nomor 2, Juli 2014 From file:///C:/Users/C/Downloads/5001- 
9665-2-PB\%20(1).pdf diakses pada tanggal 3 Juli 2016 pukul 22:33 WIB Wudianto R, (2008). Petunjuk

Penggunaan Pestisida. Jakarta : Swadaya

Yuantari MGC, (2009). Studi Ekonomi Lingkungan Penggunaan Pestisida dan Dampkanya pada Kesehatan Petani di Area Pertanian Hortikultura Desa Sumber Rejo Kecamatan Ngablak Kabupaten Magelang Jawa Tengah. Tesis. Semarang : Program Studi Magister Kesehatan Lingkungan Universitas Diponegoro

Zuraida, (2012). Faktor yang Berhubungan dengan Tingkat Keracunan Pestisida pada petani di Desa Srimahi Tambun Utara Bekasi tahun 2011. Skripsi. Jakarta: Program Studi Sarjana Kesehatan Masyarakkat Universitas Indonesia 